\title{
Physiological responses of estuarine animals to cadmium pollution
}

\author{
H. Theede \\ Institut für Meereskunde an der Universität Kiel; \\ Düsternbrooker Weg 20, D-2300 Kiel 1, Federal Republic of Germany
}

\begin{abstract}
Toxic effects of cadmium contamination may be observed at all levels of organismic organization. In estuarine areas the sensitivity of euryhaline species to acute Cd toxicity is strongly modified by various abiotic factors, whereas long-term threshold values are less dependent on environmental parameters. Experiments with larval stages of the mollusc Mytilus edulis reveal that $\mathrm{Cd}$ effects on life functions such as development and growth are differentially modified by temperature and salinity. High Cd concentrations can be accumulated by adult bivalves of coastal areas without signs of physiological damage. Mechanisms of heavy-metal detoxication in these molluscs seem to be quite different from those known to exist in vertebrates. Among decapod crustaceans, stenoecous species tend to exhibit higher rates of Cd uptake than euryoecous ones. Rates of $\mathrm{Cd}$ uptake and of accumulation depend on external and internal factors. In adult Nereis succinea individuals sublethal $\mathrm{Cd}$ effects have been recorded on growth and food conversion (in terms of energy content).
\end{abstract}

\section{INTRODUCTION}

Cadmium, one of the most toxic heavy metals, enters the environment from natural sources and as a result of man's activity, e. g. from combustion of coal and oil, the zinc industry, the recycling of scrap metal, plastics, cadmium paints and electroplating works (Goldberg, 1976). It was first recognized as an environmental pollutant after the outbreak of "itai itai" disease in Japan (Kobayashi, 1971; Douglas-Wilson, 1972). Local Cd pollution, particularly in heavily industrialized areas, cannot be eliminated at present.

In the marine environment, mainly coastal and estuarine areas are affected by $\mathrm{Cd}$ pollution. To evaluate the possible danger arising from contamination with this heavy metal, it is necessary to understand the mechanisms of its sublethal effects. The influence of cadmium has been observed on different types of organisms and all levels of biological organization. This report summarizes recent studies carried out within my working group on acute and chronic toxic effects of cadmium on marine animals under experimental conditions prevailing in coastal areas and estuaries. In addition, observations on accumulation and elimination of this heavy metal and sublethal effects on metabolism are reported. Pertinent literature is reviewed in context with these studies.

\section{GENERAL ASPECTS OF TOXICITY}

The mechanism of cadmium toxicity is complex and not yet fully understood. Indication of the toxic effects of increased Cd levels may be found at all levels of organismic structure and function. 
At the molecular level essential metals at active sites of enzymes or membrane proteins are competitively exchanged by $\mathrm{Cd}$. Its reaction with biologically active groups (e. g. carboxyl, phenoxyl, sulphhydril, disulphide and phosphate groups) seems to be of basic significance for its toxic action (Friberg et al., 1976). Many enzymes are known to be inhibited by Cd (e.g. ATPase, phosphatase, carbohydrase, peptidase, aldolase) (Vallee \& Ulmer, 1972; Schröder \& Alsen, 1976). However, in specific cases the vast number of possible interactions makes it difficult to pinpoint the main molecular causes of toxic effects.

At the subcellular level, Moore \& Stebbing (1976) found in marine hydroid polyps that $\mathrm{Cd}$ may weaken the lysosome membranes and causes lysosomal enzymes to be released to the cell. The causes for cellular dysfunctions under the influence of Cd have to be sought in the above-mentioned molecular and subcellular effects. For example, decreased absorption of calcium, iron (Larsson et al., 1976) and amino acids (Siebers \& Ehlers, 1979) and the reduction of active reabsorption by kidney tubuli cells may be due to the inhibition of certain active transport mechanisms. Membrane permeabilities also seem to be affected.

In vertebrates (fish and mammals) the kidney appears to be the critical organ (for literature consult: Friberg et al., 1976; Schröder \& Alsen, 1976; Umweltbundesamt, 1977). When a certain Cd level (about $200 \mu \mathrm{g} \mathrm{g}^{-1}$ fresh weight in the renal cortex) is reached, dysfunction of tubuli results in excretion of high quantities of proteins, amino

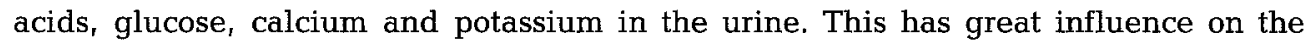
composition of the blood. Loss of Ca leads to bone decalcification, skeletal deformation, bone shortening and brittleness in "itai itai" disease. In addition, lack of Ca and K has neuromuscular effects. Other organs - the lungs in terrestrial and gills in aquatic animals, the liver and hormone systems (e. g. the adrenal cortex system and the insulin producing $B$-cells in the pancreas) - may also be affected by Cd contamination (cf. Scholz et al., 1978).

At the organismic level in vertebrates, "itai itai" disease with kidney damage, Ca loss and the above-mentioned, painful skeletal deformations have been described by Friberg et al. (1976). In vertebrates and invertebrates, effects of Cd on growth (Stebbing, 1976; Paffenhöfer, 1978; von Westernhagen et al., 1978; Stebbing \& Hiby, 1979), embryo and larval development (Calabrese et al., 1973; Mirkes et al., 1978; Reish \& Carr, 1978; Alderdice et al., 1979; Klöckner, 1979; Lehnberg \& Theede, 1979), and the alteration of various physiological functions (e. g. osmoregulation, excretion, respiration) (MacInnes \& Thurberg, 1973; Thurberg et al., 1973; Dawson et al., 1977; Thurberg et al., 1977) and behaviour (Martin et al., 1975; Eldon \& Kristoffersson, 1978) have been observed.

\section{EFFECTS OF ENVIRONMENTAL FACTORS ON TOXICITY}

Where ecologically valid conclusions are sought, only sensitive species are suitable as test organis ms for the indication of toxic substances. These are, for example, larvae of oysters and crustaceans or fish embryos, which are considerably more sensitive to heavy metals than are the reproductive adult stages. Marine hydroid polyps also respond sensitively to heavy metals (Karbe, 1972; Stebbing, 1976; Fischer, 1978): e. g. Laomedea loveni responds even to cadmium concentrations in the low $\mu \mathrm{g}^{-1}$ range 
(Scholz et al., 1978; Theede et al., 1979b). However, experimental determination of tolerance limits must take abiotic environmental factors into account, because they may be of importance for in-situ survival, especially in estuaries and coastal areas (Eisler, 1971; Olson \& Harrel, 1973; von Westernhagen et al., 1974; Jones, 1975; Rosenberg \& Costlow, 1976; Sullivan, 1977; Voyer et al., 1977; Weis \& Weis, 1978; Lehnberg \& Theede, 1979; Theede et al., 1979b).

We have studied the effects of temperature and salinity on the acute toxicity of cadmium in marine Hydrozoa. It was clearly shown that the susceptibility to cadmium of the hydroid polyp Laomedea loveni depends significantly on temperature and salinity (Fig. 1). The polyps are most tolerant to $\mathrm{Cd}$ at low temperatures and high salinities. At higher temperatures and lower salinities they are more sensitive. After 7 days of exposure at $17.5^{\circ} \mathrm{C}$ and $10 \% \mathrm{~S}$, irreversible retraction of $50 \%$ of the hydranths takes

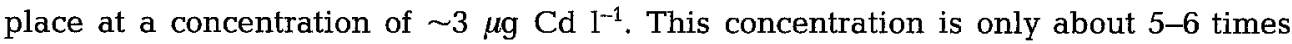
higher than the highest $\mathrm{Cd}$ concentration recorded in the heavily contaminated inner Kiel Fjord (western Baltic Sea). It is 10-100 times higher than the estimated average Cd concentration in the Baltic Sea (Theede et al., 1979b).

These results indicate that marine organisms living near their distributional limits under estuarine or the brackish-water conditions of the Baltic Sea tend to suffer from considerably lower pollution levels than those living under optimal environmental conditions. Consequently, critical limits for acute toxicity established under normal marine conditions may not automatically be applicable to conditions prevailing in estuaries or in the Baltic Sea (Theede et al., 1979b). This may also explain the more

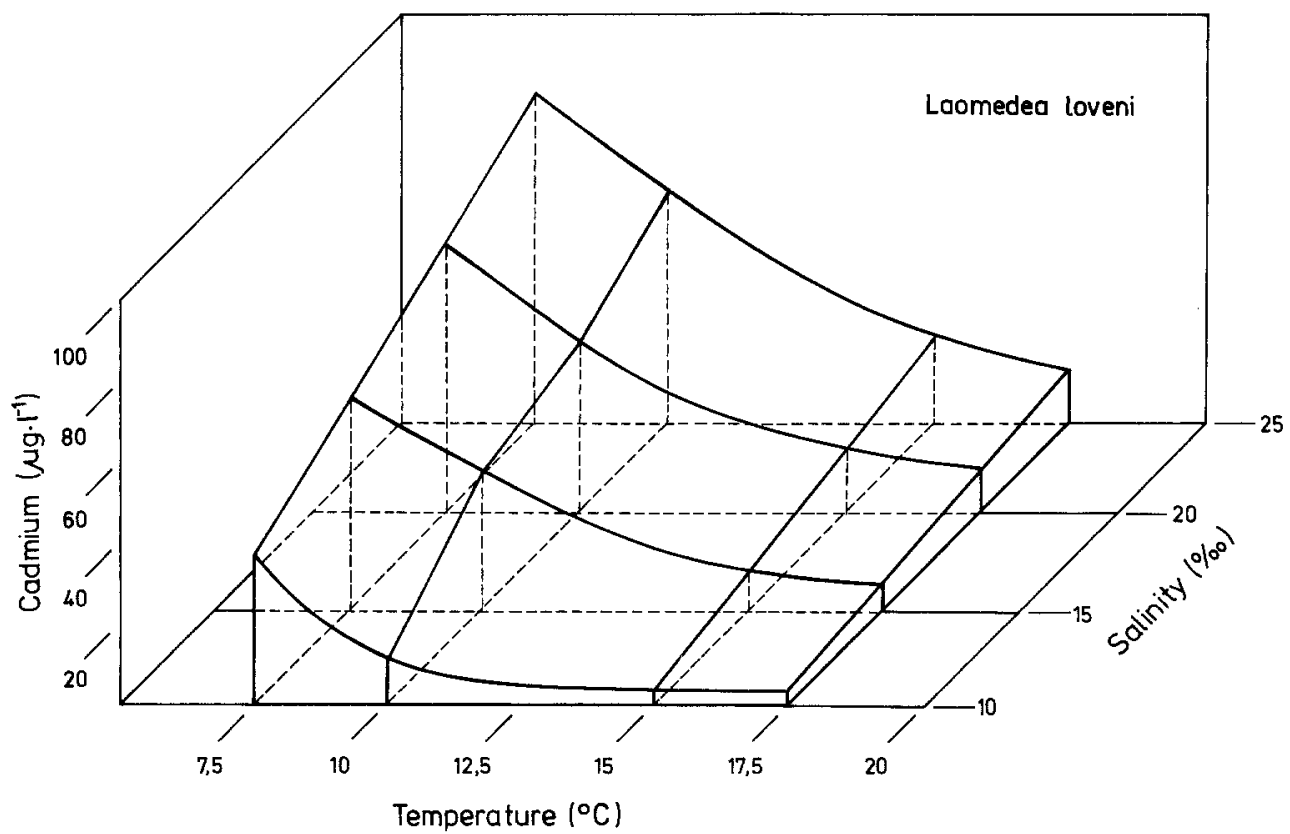

Fig. 1. Laomedea loveni. Temperature and salinity effects on the acute toxicity of cadmium. $50 \%$ irreversible retraction of polyps after 7 days of exposure to different factor combinations are indicated (after Theede et al, 1979b, modified) 
pronounced diminution of marine and/or limnic organisms due to toxic substances in brackish waters, where the organisms are already living in conditions close to their tolerance limits.

It is interesting to note that the strongly modifying effects of temperature and salinity on the acute toxicity of cadmium may be reduced in long-term experiments over a period of several weeks as shown by studies on Clava multicornis (Fischer, 1978; Scholz et al., 1978) (Fig. 2). Chronic toxicity is then more or less independent of the abiotic factors mentioned. The tolerance level in long-term experiments is reduced to values that are reached in short-term experiments only under unfavourable abiotic conditions.

Further experiments on interactions between abiotic factors and Cd were carried out with early life stages of Mytilus edulis (Lehnberg \& Theede, 1979). The trochophora stage proved to be sensitive to $\mathrm{Cd}$ concentrations of about $50 \mu \mathrm{g} \mathrm{l^{-1 }}$. It is interesting to note that the optimum salinity for development from the trochophora to the veliger stage is shifted to higher salinities when the Cd concentration of the medium is increased. A

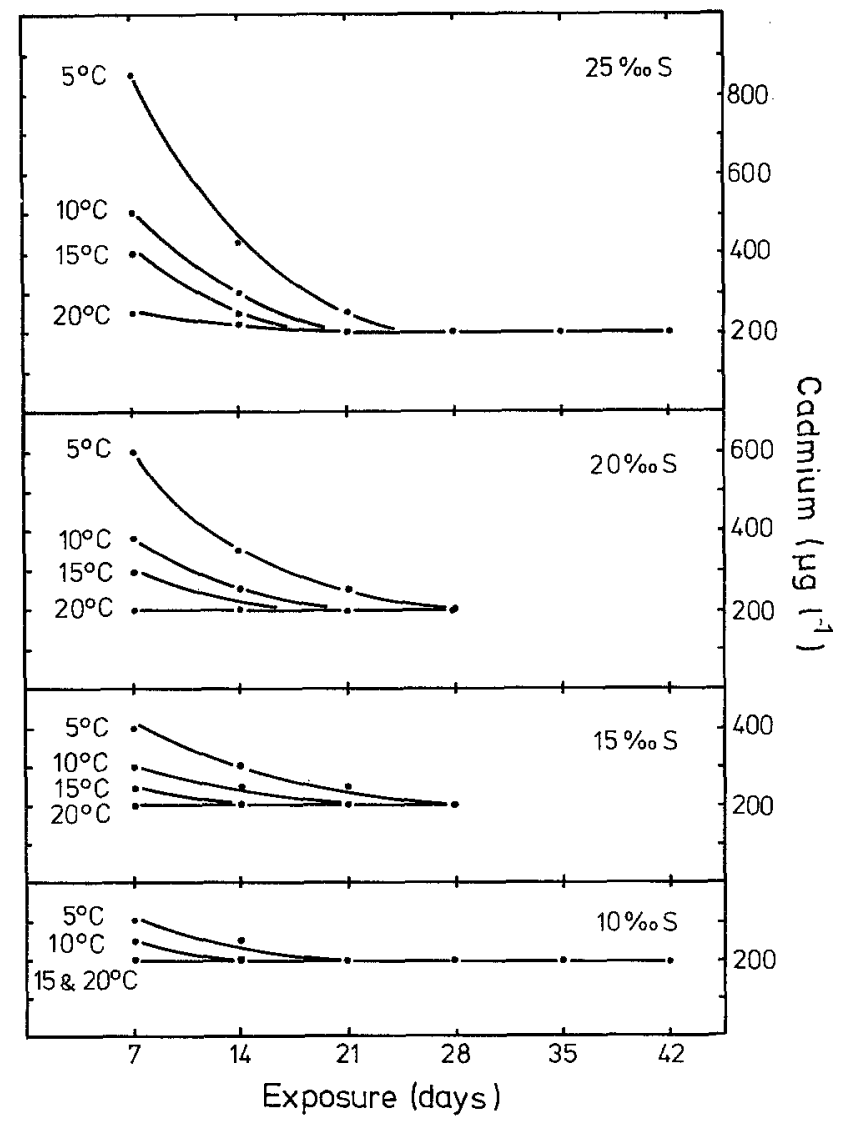

Fig. 2. Clava multicornis. Changes of the modifying effects of temperature and salinity during transition from acute to chronic toxicity of cadmium. The graph indicates the upper limits of Cd concentrations at which feeding responses occurred (after Fischer, 1978; and Scholz et al., 1978) 
change of Cd concentration from 0 to $50 \mu \mathrm{g}^{-1}$ produces a shift of the optimum from 25 to $33 \%$ S $\left(12{ }^{\circ} \mathrm{C}\right)$. The magnitude of this effect shows that even small $\mathrm{Cd}$ concentrations could shift the salinity demand for optimal development to such an extent that it is outside the range accessible to Baltic individuals (Lehnberg \& Theede, 1979). Comparable relationships have been reported for developing herring eggs by von Westernhagen et al. (1974).

In this context an interaction between $\mathrm{Cd}$ and $\mathrm{Ca}$ of the sea water is suggested. Developing mussel veligers seem to have an elevated Ca demand because of early shell construction. A shift of optimal salinity to higher salt concentrations represents an increased Ca supply, compensating the "competitor" cadmium. Deteriorations of veliger shell structure under the influence of $\mathrm{Cd}$ indicate such interactions of $\mathrm{Cd}$ and $\mathrm{Ca}$. With transition to the later veliger stage the tolerance to low salinity becomes higher and the observed cadmium/salinity interaction is reversed. Increasing Cd concentration shifts the optima for growth (and to a less extent for survival) to lower salinities.

These results show that (1) the temperature and salinity range required for larval development is altered by $\mathrm{Cd}$, and (2) sublethal $\mathrm{Cd}$ concentrations may influence the sensitive interrelationships between the reactions of larvae and the natural environmental conditions.

\section{ASPECTS OF ACCUMULATION AND ELIMINATION}

In contrast to the above-mentioned cnidarians and larval stages, adult molluscs (Brooks \& Rumsby, 1967; Eisler et al., 1972; Nickless et al., 1972; Peden et al., 1973; Phillips, 1976a) and adult crustaceans (Wright, 1977a, b, c) are able to accumulate high amounts of heavy metals without obvious negative effects.

We compared mussels from different localities of the German coasts (Theede et al., 1979a). In many places of the western Baltic Sea the levels of Cd in Mytilus edulis are higher than in comparable individuals from localities of the North Sea coast. The Cd concentrations are especially high in mussels from Kiel harbour, where there is severe water contamination due to local industries and harbour facilities as well as the town's rainwater drainage system. Thus Cd contents of mussels from the inner part of the Kiel Fjord range up to $30 \mathrm{mg} \mathrm{kg}^{-1}$ (per dry weight of soft parts). In the outer part of the Kiel Bay Cd values in mussels generally range between 1 and $4 \mathrm{mg} \mathrm{kg}^{-1}$.

The high capacity of mussels for accumulating heavy metals is one reason for considering these animals as suitable or gan is $\mathrm{ms}$ for monitoring heavy-metal pollution (Phillips, 1976a; b). Schulz-Baldes (1973) and Scholz (1980) found a partial linear relation between heavy-metal content of sea water and that of mussels. However, these animals absorb heavy metals not only from the water and their organic food but also from inorganic particulate matter. Bottom dwellers may take in more $\mathrm{Cd}$, e. g. by filtration of suspended organic and inorganic matter containing $\mathrm{Cd}$. Therefore mussels from the sea floor often tend to have a higher $\mathrm{Cd}$ content than specimens living further above the bottom (e. g. on piles). There are also correlations of Cd content in mussels with size of the individuals and season (Theede et al., 1979a). It must also be considered that uptake rates may strongly depend on abiotic factors like temperature and osmotic value of the sea water (Phillips, 1976; George et al., 1978). In addition, elimination rates in marine invertebrates may be relatively high under certain conditions. 
Vertebrates, which are able to store fairly large quantities of heavy metals in liver and kidney by binding them to special metalloproteins, so-called metallothioneins, have long biological half times for $\mathrm{Cd}$ in the magnitude of months or years (Table 1). However, in invertebrates, e. g. Carcinus maenas and Mytilus edulis, biological half times between $1 \frac{1 / 2}{2}$ weeks and about two months were observed when the animals had accumulated high amounts of cadmium from the water under experimental conditions. However, according to Peden et al. (1973) there was almost no elimination of this metal within 3 to 7 weeks, when Carcinus maenas, Patella vulgata and Nucella lapillus individuals, which had accumulated cadmium under contaminated field conditions (Cd content of sea water $\left.0.01 \mathrm{mg} \mathrm{l}^{-1}\right)$ were transferred to an uncontaminated estuary $(0.0002$ $\mathrm{mg} \mathrm{Cd} \mathrm{l}^{-1}$ ). The ranges of the half times found indicate that the metal may be bound within different compartments (Coombs \& George, 1979; Janssen \& Scholz, 1979; Scholz, 1980 ), from which it will be released at different rates. In addition, the difference in half times of vertebrates and invertebrates raises the question whether there are fundamental differences in the mechanism of heavy-metal detoxication in both systematic groups. This point is dealt with in detail by Scholz $(1979,1980)$.

Table 1. Biological half times $\left(\mathrm{t}_{1 / 2}\right)$ for $\mathrm{Cd}$ in various animal species

\begin{tabular}{|lcl|}
\hline Organism & \multicolumn{1}{c|}{$\mathrm{t}_{1 / 2}$} & \multicolumn{1}{c|}{ Authors } \\
\hline mouse & 100 days & Friberg et al. (1976) \\
rat & 200 days & Friberg et al. (1976) \\
man & $10-30$ years & Friberg et al. (1976) \\
plaice & 140 days & Pentreath (1977) \\
seaskater & 20 days & Schulz-Baldes \& Cheng (1979) \\
blue crab & $12-64^{*}$ days & Wright (1977); ${ }^{*}$ Ehlers (unpubl.) \\
mussel & $14-29$ days & Scholz (1980) \\
\hline
\end{tabular}

\section{SOME METABOLIC RESPONSES}

I should like to add a few remarks on some recently observed influences of sublethal $\mathrm{Cd}$ contamination on metabolic processes of adult invertebrates. In decapod crustaceans it has been observed that $\mathrm{Cd}$ uptake rate decreases in the order: Eupagurus bernhardus $>$ Carcinus maenas $>$ Eriocheir sinensis. In this sequence the last species is the most euryhaline and euryoecous one. When these animals are fed with Mytilus food and kept for 4 weeks in sea water with different Cd concentrations, there is an increase in water content in the contaminated animals: At about $100 \mu \mathrm{g} \mathrm{Cd} \mathrm{^{-1 }}$ the water content of Eupagurus increased by nearly $10 \%$; at about $500 \mu \mathrm{g} \mathrm{Cd} \mathrm{l^{-1 }}$ the effect in Eriocheir sinensis is an increase of about $2.5 \%$ (unpublished results of Theede \& Baukloh).

In Metridium senile the protein content decreases more noticeably when the animals are fed or starved in Cd-containing water. The effect is more pronounced in the smaller individuals, which take up Cd more rapidly. In animals obtained from their natural habitat an inverse relation between $\mathrm{Cd}$ content and protein content appears to exist (Theede \& Baukloh, unpublished). 


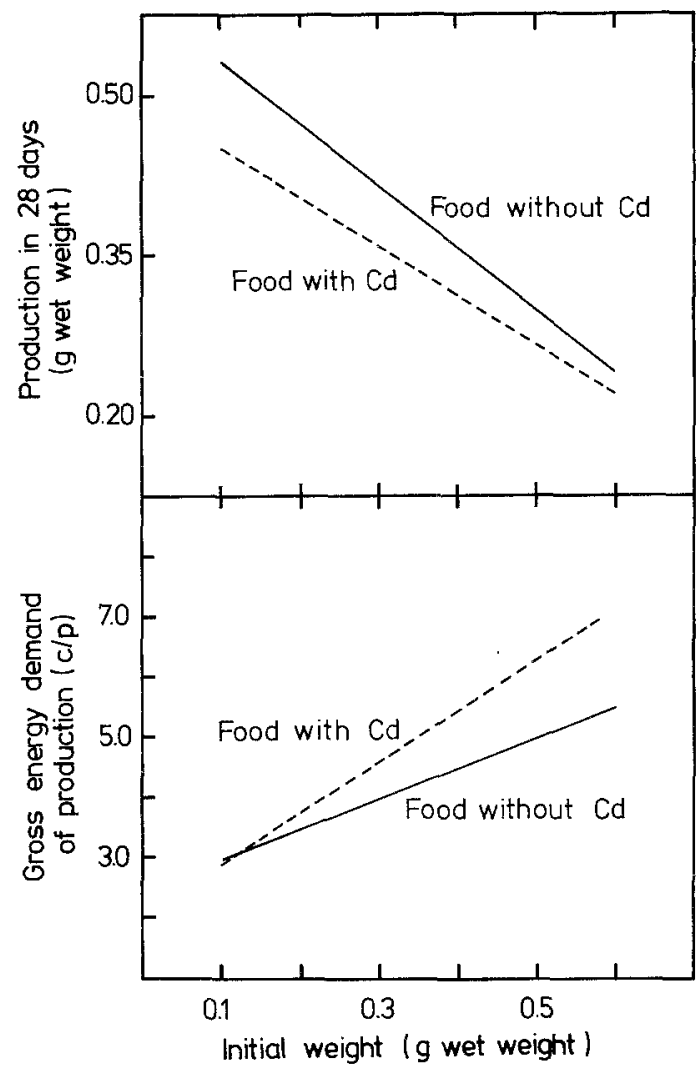

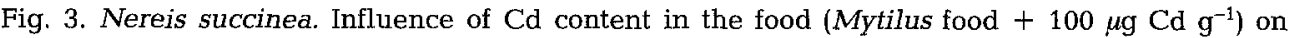
production (relation of consumed to produced energy) in relation to initial body weight $\left(12{ }^{\circ} \mathrm{C}, 17 \%\right.$ S) (after Neuhoff, unpublished)

In Nereis succinea from the western Baltic Sea addition of Cd to the food $(30-100 \mu \mathrm{g}$ $\mathrm{Cd} \mathrm{g}^{-1}$ dry weight of food) resulted in a reduced growth rate and a higher gross energy demand for production (higher relation of consumed to produced energy) (Fig. 3). These relations seem to depend on the size of the individuals and season. From a decrease of adenylate energy charge after $\mathrm{Cd}$ contamination it could be concluded that energy metabolism was impaired. However, biochemical composition of the worms was more or less unaffected (Neuhoff, in preparation). For explanation I refer to results of Calabrese et al. (1977) who reported inhibition and induction of certain enzymes and a partial loss of control of the activities of enzymes involved in the mobilization of energy. More detailed information of this kind about effects of cadmium and other heavy metals may lead to further insights into the observed metabolic disorders.

\section{LITERATURE CITED}

Alderdice, D. F., Rosenthal, H. \& Velsen, F. P. J., 1979. Influence of salinity and cadmium on capsule strength in Pacific herring eggs. - Helgoländer wiss. Meeresunters. 32, 149-162.

Brooks, R. R. \& Rumsby, M. G., 1967. Studies on the uptake of cadmium by the oyster Ostrea sinuata (Lamarck). - Aust. J. mar. Freshwat. Res. 18, 53-61. 
Calabrese, A., Collier, R. S., Nelson, D. A. \& MacInnes, J. R., 1973. The toxicity of heavy metals to embryos of the American oyster Crassostrea virginica. - Mar. Biol. 18, 162-166.

Calabrese, A., Thurberg, F. P. \& Gould, E., 1977. Effects of cadmium, mercury and silver on marine animals. - Mar. Fish. Rev. $39(4), 5-11$.

Coombs, T. L. \& George, S. G., 1978. Mechanisms of immobilization and detoxication of metals in marine organisms. In: Physiology and behaviour of marine organisms. Ed. by D. S. McLusky \& A. J. Berry. Pergamon Press, Oxford, 179-187.

Dawson, M. A., Gould, E., Thurberg, F. P. \& Calabrese, A., 1977. Physiological response of juvenile striped bass, Morone saxatilis, to low levels of cadmium and mercury. - Chesapeake Sci. 18, 353-359.

Douglas-Wilson, I., 1972. Cadmium pollution and itai itai disease. - Lancet 1, 382-383.

Eisler, R., 1971. Cadmium poisoning in Fundulus heteroclitus (Pisces: Cyprinodontidae) and other marine organisms. - J. Fish. Res. Bd Can. 28, 1225-1234.

Eisler, R., Zaroogian, G. E. \& Hennekey, R. J., 1972. Cadmium uptake by marine organisms. - J. Fish. Res. Bd Can. 29, 1367-1369.

Eldon, J. \& Kristoffersson, R., 1978. Factors affecting the burrowing activity of Macoma balthica (L.). - Ann. zool. Fenn. 15, 127-131.

Fischer, H., 1978. Hydroids in biotest: Clava multicornis exposed to cadmium. - Kieler Meeresforsch. Sonderh. 4, 327-334.

Friberg, L., Piscator, M., Nordberg, G. F. \& Kjellström, T. (Ed.), 1976. Cadmium in the environment. CRC-Press, Ohio, $284 \mathrm{pp}$.

George, S. G., Carpene, E. \& Coombs, T. L., 1978. The effect of salinity on the uptake of cadmium by the common mussel Mytilus edulis (L.). In: Physiology and behaviour of marine organisms. Ed. by D. S. McLusky \& A. J. Berry. Pergamon Press, Oxford, 189-193.

Goldberg, E. D., 1976. The health of the oceans. Unesco Press, Paris, $172 \mathrm{pp}$.

Janssen, H. H. \& Scholz, N., 1979. Uptake and cellular distribution of cadmium in Mytilus edulis. Mar. Biol. 55, 133-141.

Jones, M. B., 1975. Synergistic effects of salinity, temperature and heavy metals on mortality and osmoregulation in marine and estuarine isopods (Crustacea). - Mar. Biol. 30, 13-20.

Karbe, L., 1972. Marine Hydroiden als Testorganismen zur Prüfung der Toxizität von Abwasserstoffen. Die Wirkung von Schwermetallen auf Kolonien von Eirene viridula. - Mar. Biol. 12, 316-328.

Klöckner, K., 1979. Uptake and accumulation of cadmium by Ophryotrocha diadema (Polychaeta). Mar. Ecol. Prog. Ser. 1, 71-76.

Kobayashi, J., 1971. Relation between "itai-itai" disease and the pollution of river water by cadmium from a mine. - Adv. Wat. Pollut. Res, 1, 1-32.

Larsson, A., Bengtsson, B.-E. \& Svanberg, O., 1976. Effects of pollutants on aquatic organisms. Ed. by A. P. M. Lockwood. Cambridge Univ. Press, Cambridge, 35-45.

Lehnberg, W. \& Theede, H., 1979. Kombinierte Wirkungen von Temperatur, Salzgehalt und Cadmium auf Entwicklung, Wachstum und Mortalität der Larven von Mytilus edulis aus der westlichen Ostsee. - Helgoländer wiss. Meeresunters. 32, 179-199.

MacInnes, J. R. \& Thurberg, F. P., 1973. Effects of metals on the behaviour and oxygen consumption of the mud snail. - Mar. Pollut. Bull. 4, 185-186.

Martin, J. M., Plitz, F. M. \& Reish, D. J., 1975. Studies on the Mytilus edulis community in Alamitos Bay, California. V. The effects of heavy metals on byssal thread production. - Veliger 18, 183-188.

Mirkes, D. Z., Vernberg, W. B. \& DeCoursey, P. J., 1978. Effects of cadmium and mercury on the behavioral responses and development of Eurypanopeus depressus larvae. - Mar. Biol. 47, 143-147.

Moore, M. N. \& Stebbing, A. R. D., 1976. The quantitative cytochemical effects of three metal ions on a lysosomal hydrolase of a hydroid. - J. mar. biol. Ass. U. K. 56, 995-1005.

Nickless, G., Stenner, R. \& Terrille, N., 1972. Distribution of cadmium, lead and zinc in the Bristol Channel. - Mar. Pollut. Bull. 3, 188-190.

Olson, K. R. \& Harrel, R. C., 1973. Effect of salinity on acute toxicity of mercury, copper, and chromium for Rangia cunaeata (Pelecypoda, Mactricidae). - Contr. mar. Sci. 17, 9-13.

Paffenhöfer, G. A. \& Knowles, S. C., 1978. Laboratory experiments on feeding, growth and fecundity 
of and effects of cadmium on Pseudodiaptomus. - Bull. mar. Sci. 28, 574-580.

Peden, J. D., Crothers, J. H., Waterfall, C. E. \& Beasley, J., 1973. Heavy metals in Somerset marine organisms. - Mar. Pollut. Bull 4, 7-9.

Pentreath, R. J., 1973. The accumulation from water of $\mathrm{Zn}^{65}, \mathrm{Mn}^{54}, \mathrm{Co}^{58}$ and $\mathrm{Fe}^{59}$ by the mussel Mytilus edulis. - J. mar. biol. Ass. U. K. 53, 127-143.

Phillips, D. J. H., 1976a. The common mussel Mytilus edulis as an indicator of pollution by zinc, cadmium, lead and copper. I. Effects of environmental variables on uptake of metals. - Mar. Biol. $38,59-69$.

Phillips, D. J. H., 1976b. The common mussel Mytilus edulis as an indicator of pollution by zinc, cadmium, lead and copper. II. Relationship of metals in the mussel to those discharged by industry. - Mar. Biol. 38, 71-80.

Reish, D. J. \& Carr, R. S., 1978. The effect of heavy metals on the survival, reproduction, development, and life cycles for two species of polychaetous annelids. - Mar. Pollut. Bull. 9, 24-27.

Rosenberg, R. \& Costlow, J. D. Jr., 1976. Synergistic effects of cadmium and salinity combined with constant cycling temperatures on the larval development of two estuarine crab species. - Mar. Biol. 38, 291-303.

Scholz, N., Fischer, H. \& Theede, H., 1978. Toxic effects and accumulation of cadmium in some benthic organisms of the Baltic. - Kieler Meeresforsch. Sonderh. 4, 317-326.

Scholz, N., 1979. Cadmium in Mytilus edulis. Untersuchungen über Aufnahme, Verbleib und Abgabe. Dissertation, Math.-Nat. Fak., Universität Kiel, 93 pp.

Scholz, N., 1980. Accumulation, loss and molecular distribution of cadmium in Mytilus edulis. Helgoländer Meeresunters. 33, 68-78.

Schröder, C. \& Alsen C., 1976. Die Wirkungen von Cd und Zn und deren Interaktionen in biologischen Systemen. - Schriftenreihe der Untersuchungsstelle für Umwelttoxikologie des Landes Schleswig-Holstein, 1-135.

Schulz-Baldes, M., 1973. Die Miesmuschel, Mytilus edulis, als Indikator für die Bleikonzentration im Weserästuar und in der Deutschen Bucht. - Mar. Biol. 21, 98-102.

Schulz-Baldes, M. \& Cheng, L., 1979. Uptake and loss of radioactive cadmium by the seaskater Halobates robustus (Heteroptera: Gerridae). - Mar. Biol. 52, 253-258.

Siebers, D. \& Ehlers, U., 1979. Heavy metal action on transintergumentary absorption of glycine in two annelid species. - Mar. Biol. 50, 175-179.

Sullivan, J. K., 1977. Effects of salinity and temperature on the acute toxicity of cadmium to the estuarine crab Paragrapsus gaimardii (Milne Edwards). - Aust. J. mar. Freshwat. Res. 28, 739-743.

Stebbing, A. R. D., 1976. The effects of low metal levels on a clonal hydroid. -J. mar. biol. Ass. U. K. $56,977-994$.

Stebbing, A. R. D. \& Hiby, A. R., 1979. Cyclical fluctuations in the growth rate of stressed hydroid colonies. In: Cyclic phenomena in marine plants and animals. Ed. by E. Naylor \& R. G. Hartnoll. Pergamon Press, Oxford, 165-172.

Theede, H., Andersson, I. \& Lehnberg, W., 1979a. Cadmium in Mytilus edulis from German coastal waters. - Meeresforsch. 27, 147-155.

Theede, H., Scholz, N. \& Fischer, H., 1979b. Temperature and salinity effects on the acute toxicity of cadmium to Laomedea loveni (Hydrozoa). - Mar. Ecol. Prog. Ser. 1, 13-19.

Thurberg, F. P., Dawson, M. A. \& Collier, R. S., 1973. Effects of copper and cadmium on osmoregulation and oxygen consumption in two species of estuarine crabs. - Mar. Biol. 23, 171-175.

Thurberg, F. P., Calabrese, A., Gould, E., Greig, R. A., Dawson, M. A. \& Tucker, R. K., 1977. Response of the lobster, Homarus americanus, to sublethal levels of cadmium and mercury. In: Physiological responses of marine biota to pollutants. Ed. by F. J. Vernberg, A. Calabrese, F. P. Thurberg \& W. B. Vernberg. Acad. Press, New York, 185-197.

Umweltbundesamt, 1977. Luftqualitätskriterium für Cadmium. - Berichte des Umweltbundesamtes $4,1-158$.

Vallee, B. L. \& Ulmer, D. D., 1972. Biochemical effects of mercury, cadmium and lead. - Rev. Biochem. 41, 91-128.

Voyer, R. A., Wentworth, C. E., Barry, E. P. \& R. J. Hennekey, 1977. Viability of embryos of the winter flounder Pseudopleuronectes americanus exposed to combinations of cadmium and salinity at selected temperatures. - Mar. Biol. 44, 117-124. 
Weis, P. \& Weis, J.S., 1978. Methylmercury inhibition of fin regeneration in fishes and its interaction with salinity and cadmium. - Estuar. coast. mar. Sci. 6, 327-334.

Westernhagen, H. von, Rosenthal, H. \& Sperling, K.-R., 1974. Combined effects of cadmium and salinity on development and survival of herring eggs. - Helgoländer wiss. Meeresunters. 26, 416-433.

Westernhagen, H. von, Dethlefsen, V., Rosenthal, H., Fürstenberg, G. \& Klinckmann, J., 1978. Fate and effects of cadmium in an experimental marine ecosystem. - Helgoländer wiss. Meeresunters. $31,471-484$.

Wright, D. A., 1977a. The effect of salinity on cadmium uptake by the tissues of the shore crab Carcinus maenas. - J. exp. Biol. 67, 137-146.

Wright, D. A., 1977b. The effect of calcium on cadmium uptake by the shore crab Carcinus maenas. - J. exp. Biol. 67, 163-173.

Wright, D. A., $1977 \mathrm{c}$. The uptake of cadmium into the haemolymph of the shore crab Carcinus maenas: The relationship with copper and other divalent cations. - J. exp. Biol. 67, 147-161. 